Globalization and Human Rights 
This page intentionally left blank 


\section{Globalization and Human Rights}

EDITED BY

Alison Brysk 
A portion of the royalties from this book will be donated to Human Rights Watch University, an electronic educational project under construction by Human Rights Watch. For more information, contact:

Pamela Bruns, Executive Director Human Rights Watch, California 115 oo West Olympic Blvd. Los Angeles, CA 90064

University of California Press

Berkeley and Los Angeles, California

University of California Press, Ltd.

London, England

(C) 2002 by

The Regents of the University of California

Library of Congress Cataloging-in-Publication Data

Globalization and human rights / edited by Alison Brysk.

p. $\mathrm{cm}$.

Includes bibliographical references and index.

ISBN 0-520-23237-2 (cloth : alk. paper)—ISBN 0-520-23238-o (paper : alk. paper)

1. Human rights. 2. Globalization.

I. Brysk, Alison.

JC571.G584 2002

323'.og'o511-dc2 1

2002002825

Manufactured in the United States of America
$\begin{array}{lllllllll}10 & 09 & 08 & 07 & 06 & 05 & 04 & 03 & 02\end{array}$
$\begin{array}{llllllllll}10 & 9 & 8 & 7 & 6 & 5 & 4 & 3 & 2 & 1\end{array}$

The paper used in this publication is both acid-free and totally chlorine-free (TCF). It meets the minimum requirements of ANSI/NISO Z39.48-1992 (R 1997) (Permanence of Paper).@ 